\title{
Empirical Estimate for the Maximum Element Number of a Nonredundant Configuration on Square Array Antenna
}

\author{
L. E. Kopilovich \\ O. Ya. Usikov Institute for Radiophysics and Electronics of NAS of Ukraine, \\ 12, Acad. Proskury St., Kharkiv, 61085, Ukraine \\ E-mail:kopil@ire.kharkov.ua
}

Received August 18, 2008

The maximum number of elements of a nonredundant configuration on a square array antenna is estimated empirically employing the investigated structure of differences between the elements of the configuration mapping onto the scan.

\section{Introduction}

The problem of constructing a nonredundant configuration (NRC) of elements is of urgent necessity for radio interferometry. Here, a momentous problem is how to build the NRC with the maximum number of elements to obtain the maximum number of interferometer baselines. Such NRCs on square $n \times n$ grids (so called "Golomb squares" [1]) with the maximum possible elements are found at $n \leq 22$ in a number of papers [1-7]. At the same time, the size of modern array antenna, as well as the number of its elements, can substantially exceed these values [8] that requires the elaboration of methods for building NRCs on large grids.

Such NRCs were obtained in [4] with using combinatorial constructions - cyclic difference sets (see also [9]). However, it remains unclarified to what degree the element number of the NRC thus found is close to a maximum.

The rigorous estimates for the NRC element number on a square grid were obtained in $[1,3]$, however, the former is too overrated, while for applying the latter the information on NRCs on linear grids of large lengths, unavailable to date, is required. In this connection, the obtainment of the upper estimate based on available empirical data is of interest.

\section{Analysis of the mapping structure of the NRC on the square grid scan}

Consider an arbitrary $k$-element NRC on the $n \times n$ grid and analyze the system of vector differences between its elements (see Fig. 1). Number the cells of the first grid row from 1 to $n$, of the second one - from $n+1$ to $2 n$, and so on.

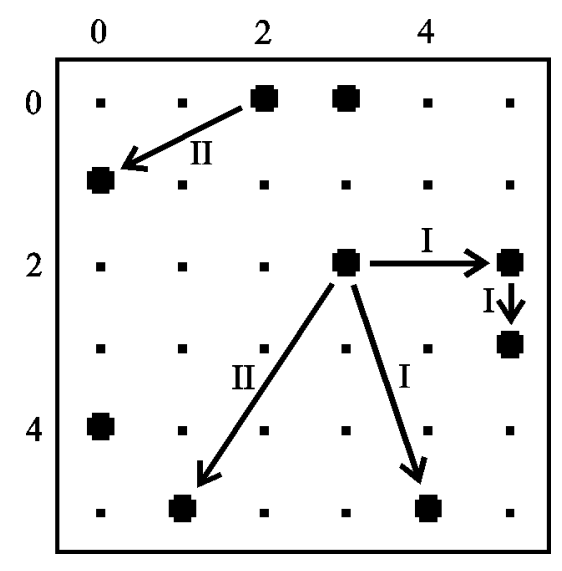

Fig. 1. An example of a nonredundant configuration (NRC) on the square grid. The NRC elements are denoted with bold dots. The vectors connecting the elements are pointed rigthwards or strictly downwards (type I) or leftwards (type II) 
The vector connecting the cells can be pointed rightwards or strictly downwards (type I), or leftwards (type II). When scanning the grid, the NRC on it passes to a point system on the segment, and the differences between these points can be either one-fold (i. e. non-repeated) or two-fold ones. Obviously, vector differences on a 2-D grid belonging to the same type cannot pass to equal differences on the scan, while only some part of these belonging to the opposite types passes to the equal ones. Thus, the share of the one-fold differences on the scan can be expected to exceed half of their total number $K=k(k-1) / 2$. Besides, it should be taken into account that the NRC placed on a square grid, the latter being rotated through $90^{\circ}$, would give an alternative point system on the scan (see Fig. 2). In addition, for most of $n$ values, at least, several different NRCs with a maximum number of elements can be built [7]. This allows suggestion that for almost all values of $n$ a maximum-element NRC on the $n \times n$ grid can be built for which the share $(\alpha)$ of the non-repeated differences on the scan exceeds $50 \%$ of their total number,

$\alpha>50 \%$.
These qualitative considerations were verified by using the available data. The $n \times n$ grids at $3 \leq n \leq 22$ with the NRCs found in $[4,6,7]$ placed on them were scanned in two variants (as in Fig. 2), and it was found out that for all $n$ in this range, except for $n=7$, this suggestion was validated at least in one of such variants (see Table 1).

Now we will seek the upper estimate for the NRC element number under the assumption that for $n>7$ a maximum-element NRC can be found for which condition (1) is fulfilled.

\section{Upper estimate of the NRC element number}

Consider a $k$-element NRC placed on the $n \times n$ grid. When scanning the grid, the NRC elements pass to a point sequence

$a_{1}<a_{2}<\ldots<a_{k}$

on the scan.

Here, we apply the approach suggested for the linear case [10]. The order of differences
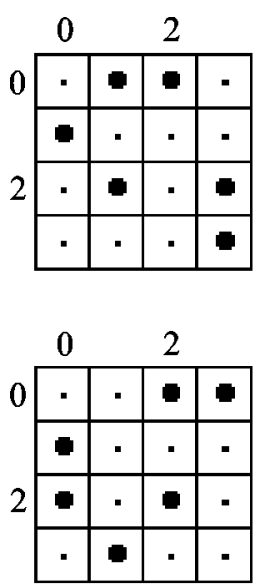

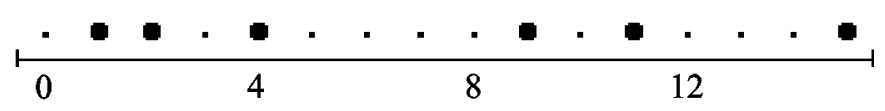

a)

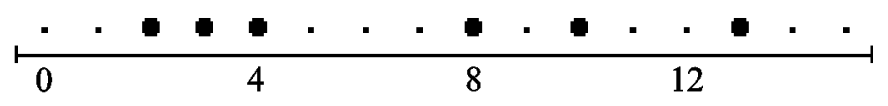

b)

Fig. 2. A grid with an NRC placed on it, and its scan (a). The same grid rotated through $90^{\circ}$, and its scan (b). The share of non-repeated differences between the points on the scan is denoted with $\alpha(\%)$ 
Table 1. The characteristics of the maximum-element NRCs and point sequences obtained from them when scanning the location grids. Here, $n$ is the grid sidelength, $k$ is the number of the NRC elements, $m$ is the number of non-repeated differences between points on the scan, and $\alpha$ is their share in the total number of differences equal to $K=k(k-1) / 2$

\begin{tabular}{c|c|c|c|c}
\hline$n$ & $k$ & $m$ & $K$ & $a(\%)$ \\
\hline 3 & 5 & 6 & 10 & 60.0 \\
4 & 6 & 11 & 15 & 73.3 \\
5 & 8 & 16 & 28 & 57.4 \\
6 & 9 & 24 & 36 & 66.7 \\
7 & 11 & 27 & 55 & 49.1 \\
8 & 12 & 34 & 66 & 51.5 \\
9 & 13 & 45 & 78 & 56.7 \\
10 & 15 & 53 & 105 & 50.5 \\
11 & 16 & 64 & 120 & 53.3 \\
12 & 17 & 82 & 136 & 60.3 \\
13 & 18 & 87 & 153 & 56.9 \\
14 & 19 & 101 & 171 & 59.1 \\
15 & 21 & 112 & 210 & 53.3 \\
16 & 22 & 125 & 231 & 54.1 \\
17 & 23 & 149 & 253 & 58.9 \\
18 & 24 & 168 & 276 & 60.9 \\
19 & 25 & 184 & 300 & 61.3 \\
20 & 26 & 198 & 325 & 60.9 \\
22 & 29 & 244 & 406 & 60.1 \\
\hline
\end{tabular}

between elements $a_{j}$ and $a_{i}$ of sequence (2), $j>i$, is the difference $j-i$, at this point, the sum of differences of the first order is

$\left(a_{2}-a_{1}\right)+\ldots+\left(a_{k}-a_{k-1}\right)<n^{2}$,

and similarly, the sum of differences of order $v$ is

$\left(a_{v+1}-a_{1}\right)+\ldots+\left(a_{k}-a_{k-v}\right)<v n^{2}$.

It follows that the sum of differences of orders up to $t$ is

$S_{t}<n^{2} t(t+1) / 2$.
On the other hand, the number of these differences is

$(k-1)+\ldots+(k-t)=k t-t(t+1) / 2=t s$,

where $s=k-(t+1) / 2,1 \leq t \leq k$.

Should the differences between the elements on the scan be all distinct then one might write

$S_{t} \geq 1+\ldots+t s$,

and comparing the last inequality with (3) find the estimate of the maximum element number. Virtually, in such a way the estimate for the maximum element number of an NRC on a linear grid can be obtained [10].

In our case, some part of differences on the scan are two-fold, but using condition (1) and with the Eq. (4) considered, we may write

$$
S_{t} \geq 2(1+\ldots+[t s / 4])+([t s / 4]+1)+\ldots+[3 t s / 4],
$$

where $[c]$ means integer part of $c$. If one writes $t s=4 r+\beta$, with the $r$ integer and $\beta=0,1,2$ or 3 , inequality (5) can be rewritten in the form

$$
S_{t} \geq 2(1+\ldots+r)+(r+1)+\ldots+(4 r+\beta-r) .
$$

When performing here the summation operations and returning again to the $t s$ one obtains

$$
S_{t} \geq \frac{5}{16}(t s)^{2}+\left(\frac{\beta}{8}+\frac{1}{2}\right) t s+\frac{1}{16} \beta^{2}>\frac{5}{16}(t s)^{2} .
$$

Further, one correlates the last inequality with (3) and obtains:

$$
\frac{5}{16}(t s)^{2}<\frac{t(t+1) n^{2}}{2}
$$

whence 
$s<n b \sqrt{1+1 / t} \cong n b(1+1 /(2 t))$,

with $b=\sqrt{8 / 5}=1.265$,

and

$k<(t+1) / 2+n b(1+1 /(2 t))=f(t)$. thus

Function $f(t)$ has its minimum at $t=\sqrt{n b}$,

$$
k<1.265 n+1.124 \sqrt{n}+0.5
$$

or $k \leq k_{e}$, where $k_{e}$ is the integer part of the expression in the right-hand side of (6).

\section{Results}

Table 2 shows the maximal found element numbers of NRCs placed on $n \times n$ grids at $n>7$ taken from [7], in comparison with their estimates as obtained by (6) and those known from literature. It can be seen that the values of $k_{e}$ are smaller than the estimates given in [1]; as for the estimates in [3], obtained only for $n \leq 11$, in this range they roughly equal to ours.

As is seen from Table 2, there is a "reserve" kept in the discrepancy between $k_{e}$ and the corresponding value of $k$. Apparently, owing to this estimate (6) is valid also for the case of a possible value of $n$ when condition (1) is not fulfilled.

The comparison of the estimates for large arrays given by (6) with the results obtained in [4] (see Table 3) shows that the number of NRC elements given by the suggested method, though not maximum, is nevertheless wholly acceptable for feasible purposes.

\section{Conclusion}

The upper estimate obtained for the element number of an NRC on a square grid is more efficient than those earlier known. It can serve a guiding line when building a large size array antenna with the maximum NRC element number.
Table 2. The estimates of the maximum number of the NRC elements on square grids. Here, $n$ and $k$ are the same as in Fig. 1, $k_{e}$ is estimated with (6), $k_{r}$ and $k_{r 1}$ are the estimates of $k$ taken from [1] and [3], respectively

\begin{tabular}{c|c|c|c|c}
\hline$n$ & $k$ & $k_{e}$ & $k_{r}$ & $k_{r 1}$ \\
\hline 8 & 12 & 13 & 13 & 13 \\
9 & 13 & 15 & 15 & 14 \\
10 & 15 & 16 & 17 & 16 \\
11 & 16 & 18 & 19 & 18 \\
12 & 17 & 19 & 21 & - \\
13 & 18 & 21 & 23 & - \\
14 & 19 & 22 & 25 & - \\
15 & 21 & 23 & 27 & - \\
16 & 22 & 25 & 28 & - \\
17 & 23 & 26 & 29 & - \\
18 & 24 & 28 & 31 & - \\
19 & 25 & 29 & 33 & - \\
20 & 26 & 30 & 34 & - \\
21 & 27 & 32 & - & - \\
22 & 29 & 33 & - & - \\
\hline
\end{tabular}

Table 3. The element numbers in the NRCs on large grids [6], and their estimates with (6)

\begin{tabular}{c|c|c}
\hline$n$ & $k$ & $k_{e}$ \\
\hline 25 & 30 & 37 \\
30 & 35 & 44 \\
40 & 47 & 58 \\
50 & 58 & 71 \\
\hline
\end{tabular}

\section{References}

1. J. P. Robinson, "Golomb rectangles", IEEE Trans, Vol. IT-31, No. 6, pp. 781-787, 1985.

2. J. B. Shearer, "Some new Golomb rectangles", Electron. J. Comb., Vol. 2, No. R12, 1995.

3. J. P. Robinson, "Golomb rectangles as folded rulers", IEEE Trans, Vol. IT-43, No. 1, pp. 290-293, 1997.

4. L. E. Kopilovich, "Nonredundant apertures for optical interferometric systems: maximization of the num- 
ber of elements", J. Mod. Opt., Vol. 45, No. 11, pp. 2417-2424, 1998.

5. J. P. Robinson, "Genetic search for Golomb arrays”, IEEE Trans, Vol. IT-46, No. 6, pp. 781-787, 2000.

6. Yu. V. Kornienko, "Construction of nonredundant antenna configurations on square grids by a random search technique", Telecommunications and Radio Engineering, Vol. 57, Nos. 2\&3, pp. 23-30, 2002.

7. J. B. Shearer "Symmetric Golomb squares", IEEE Trans, Vol. IT-50, No. 8, pp. 1846-1847, 2004.

8. R. Schultz, "Radio astronomy antennas by the Thousands", Experimental Astronomy, Vol. 17, pp. 119-139, 2004.

9. L. E. Kopilovich and L. G. Sodin, "Multielement System Design in Astronomy and Radio Science", vol. 268, Dordrecht/Boston/London: Kluwer Academic Publishers, Astrophysics and Space Science Library, 2001, 190 p.

10. B. Lindström, "On inequality for B-sequences", J. Combin. Theory, Vol. A6, No. 2, pp. 211-212, 1969.

\section{Эмпирическая оценка максимального числа элементов безызбыточной конфигурации на квадратной антенной решетке}

\section{Л. Е. Копилович}

Получена эмпирическая оценка максимального числа элементов безызбыточной конфигурации на квадратной антенной решетке, основанная на изучении структуры разностей между элементами ее отображения на развертке.

\section{Емпірична оцінка максимальної кількості елементів безнадлишкової конфігурації на квадратній антенній решітці}

\section{Л. Ю. Копилович}

Отримано емпіричну оцінку максимальної кількості елементів безнадлишкової конфігурації на квадратній антенній решітці, що грунтується на вивченні структури різниць між елементами іiі відображення на розгортці. 